\title{
Concentration of Trace Metals in Blood and the Relationship with Reproductive Hormones (Estradiol and Progesterone) of Obese Females Living Around A Mining Area in Brits, South Africa
}

\author{
G. N. Lion $\uparrow *$, G. A. Ogunbanjo** and J.O. Olowoyo* \\ *Department of Biology, Sefako Makgatho Health Sciences University, Medunsa 0204, South Africa \\ **Department of Family Medicine \& PHC, Sefako Makgatho Health Sciences University, Medunsa, 0204, South Africa \\ †Corresponding author: G. N. Lion; ntebo.lion@smu.ac.za
}

Nat. Env. \& Poll. Tech. Website: www.neptjournal.com

Received: 02-09-2019

Revised: 28-09-2019

Accepted: 07-11-2019

Key Words:

Trace metals

Reproductive hormones

Obese females

Mining area

\begin{abstract}
Obesity is a rapidly growing problem in South Africa, with $70 \%$ of women reported as being obese. Studies have reported that high levels of trace metals may impair the production of reproductive hormones, which may, in turn, interfere with normal oocyte development in females. This study investigated the concentrations of trace metals in blood samples of obese individuals living around a mining industry and examined the overall effect on reproductive hormones of these obese females. A mixed-method research approach consisting of qualitative and quantitative (cross-sectional descriptive survey) was used in the study. Only females with BMI $\geq 30$ were allowed to participate in the study. Blood samples were collected in two $5 \mathrm{~mL}$ tubes from each of the participants. Concentrations of trace metals in the blood samples were determined by the use of ICP-MS. Hormonal level measurement was also carried out. The results showed that the trace metal concentrations in the blood samples of participants were in the order $\mathrm{Mn}>\mathrm{Cr}>\mathrm{Co}>\mathrm{As}>\mathrm{Pb}>\mathrm{Cd}$. The mean concentrations of $\mathrm{Mn}, \mathrm{Cr}, \mathrm{Co}$ and As were above the WHO standards. The hormonal analysis showed that there was a positive correlation between estradiol and progesterone levels with $\mathrm{Mn}$ concentration. $\mathrm{Cr}$ and As concentrations showed a negative correlation between estradiol and progesterone levels. Also, a negative correlation was established between estradiol levels with $\mathrm{Pb}$ and $\mathrm{Cd}$ concentrations. The study showed that exposure to trace metals as pollutants may have an impact on the general and reproductive health of obese females living around mining activities.
\end{abstract}

\section{INTRODUCTION}

Trace metals occur naturally in the environment and form essential components of humans, plants and animals. However, increasing levels of these metals in the environment can adversely affect the environment and living organisms (Jarup 2003). Various sources of these elements include soil erosion, natural weathering of the earth's crust, mining, industrial effluents, urban runoff, sewage discharge geogenic, agricultural, pharmaceutical, domestic effluents, vehicular emissions and atmospheric depositions among others (Wang et al. 2005, Wang et al. 2010, Morais et al. 2012).

Mining activities in South Africa have been implicated as one of the major contributors of trace metals in the environment (Lion et al. 2012, Olowoyo et al. 2013). It has been reported that these mining activities may increase the concentration of trace metals in soil and plants around its vicinity if unchecked or uncontrolled (Koz et al. 2012, Olowoyo et al. 2013).

Trace metals enter the surroundings by natural means and through human activities. These pollutants may then find their way into the human body through occupational exposure which includes mining dust, inhalation of dust, direct ingestion of soil and water, dermal contact of contaminated soil and water, and consumption of vegetables grown in agricultural land situated near mining activities (Olowoyo $\&$ Lion 2016). The most commonly found trace metals in wastewater include $\mathrm{As}, \mathrm{Cd}, \mathrm{Cr}, \mathrm{Cu}, \mathrm{Pb}, \mathrm{Ni}$, and $\mathrm{Zn}$, all of which cause risks for human health and the environment (Lambert et al. 2000).

Various studies have been conducted to evaluate human health risks due to trace metal exposure through various exposure pathways, especially soil and food chain (MacIntosh et al. 1996, Albering et al. 1999, Hough et al. 2004, Baastrup et al. 2008, Mari et al. 2009, Man et al. 2010). Although these metals have crucial biological functions in living cells, often their chemical coordination and oxidation-reduction properties have given them an additional benefit so that they can escape control mechanisms such as homeostasis, transport, compartmentalization and binding to required cell constituents (Monisha et al. 2014). These metals bind with protein sites which are not made for them by displac- 
ing original metals from their natural binding sites causing malfunctioning of cells and ultimately toxicity. Research has also revealed that oxidative deterioration of biological macromolecules is primarily due to binding of trace metals to the DNA and nuclear proteins (Flora et al. 2008). Metals sometimes act as a pseudo element of the body while at certain times they may even interfere with metabolic processes (Monisha et al. 2014).

It was recently reported that trace metals such as, $\mathrm{Cd}$, $\mathrm{Zn}, \mathrm{Pb}, \mathrm{Ni}$, and $\mathrm{Hg}$ may exhibit endocrine-disrupting activity (Georgescu et al. 2011). Divalent metals, including $\mathrm{Pb}$ and $\mathrm{Hg}$, can initiate the estrogen receptor by interacting with amino acids at the receptor binding site (Zhang et al. 2008), and both metals exert estrogenic changes in experimental models (Choe et al. 2003). Stoica et al. (2000), also reported that Cd may obstruct the hormone-binding domain of the estrogen receptor- , thereby affecting subsequent transcriptional processes (Guével et al. 2000). A study by Georgescu et al. (2011), also revealed that the $\mathrm{Zn}$ atom from the $\mathrm{Zn}$ fingers of the estrogen receptor can be replaced by several trace metal molecules such as $\mathrm{Co}, \mathrm{Cu}, \mathrm{Cd}$, and $\mathrm{Ni}$, which then interferes with hormonal functions.

Denier et al. (2009), reported that $\mathrm{Zn}, \mathrm{Cu}$ and $\mathrm{Cd}$ were able to potentiate the estradiol-induced response in a dose-dependent manner, thus indicating that $\mathrm{Zn}$ can act as a potential endocrine disrupter by modulating the estrogenic activity of endogenous hormones (xenoestrogen).

The World Health Organization (2015), reported that more than $10 \%$ of females are severely affected by infertility. The reproductive health of females of childbearing age is currently a major worldwide public health problem. According to Mendola et al. (2007) and Bloom et al. (2011), environmental factors, such as exposure to trace metals, can cause reproductive dysfunction in females and affect their reproductive hormones. Toxic metals may induce hormonal changes affecting the menstrual cycle, ovulation, and female fertility (Sengupta 2015). Furthermore, hormones have been reported to have an affinity for trace metals. It has been reported that trace metals tend to bind to hormones at the receptors site and cause hormonal dysfunction (Georgescu et al. 2011). Metals, such as $\mathrm{Pb}, \mathrm{Cd}$, and As, are reproductive toxicants widely distributed in the environment (CDC 2005). Several epidemiological studies on menstruation have indicated that metals affect hormone levels (Mednola et al. 2007, Gallagher 2009, Krieg 2007, Nagata 2005, Guo 2011). Furthermore, $\mathrm{Pb}$ and $\mathrm{Cd}$ have been identified in human follicular fluid (Paksy 2001, Al Saleh 2007, Langley 2014) and As was shown to cause dose-related increases in ovarian tumours (Tokar 2011). Chang et al. (2006), indicated that females with blood $\mathrm{Pb}$ levels higher than $25 \mu \mathrm{g} / \mathrm{L}$ had a 3-fold increased risk of infertility compared with females whose blood $\mathrm{Pb}$ levels were less than $25 \mu \mathrm{g} / \mathrm{L}$.

This study addresses the devastating effect of trace metals in blood and the relationship on reproductive hormones (estradiol and progesterone) of obese females exposed to mining activities. This is due to the recent report that showed that $70 \%$ of females in South Africa have been reported as either overweight or obese. According to the survey conducted by the South African Medical Research Council (SAMRC), Statistics South Africa and the Department of Health (2015), females are more prone to extra weight/ pounds than their male counterparts (De Ridder \& Coetzee 2015). More devastating report for obese females is the fact that trace metals have recently been linked to health issues associated with obesity. Furthermore, significant relationships between metallic elements (including blood $\mathrm{Zn}, \mathrm{Cu}$, $\mathrm{Mn}$, and $\mathrm{Hg}$ ) with obesity, and a positive relationship with body mass index (BMI), low-density lipoprotein cholesterol (LDL - C), triglyceride, total cholesterol, and homeostatic model assessment of insulin resistant (HOMA - IR) has been demonstrated in the literature (Feldman et al. 2015, Fan et al. 2017).

However, studies relating to trace metals and their role on the reproductive hormones such as estradiol and progesterone especially in obese females exposed to mining activities have not been done in South Africa, to the best of our knowledge. Even though it has been highlighted that $70 \%$ of females are classified as either obese or overweight. Literature also indicates that increasing interest should also be directed towards interactions between different elements (Blazewicz et al. 2013) as a means of understanding the role of trace metals exposure to human health which includes reproduction.

The toxicity of trace metals disrupts the body's natural ability to balance blood sugar and metabolize cholesterol (Feldman et al. 2015). Obesity has also been associated with pregnancy complications and plays a role in increasing fertility problems, e.g. gestational diabetes, pre-eclampsia, sleep apnoea (Tasneem et al. 2008). It has also been reported that trace metals may impair the production of reproductive hormones, which may, in turn, interfere with normal oocyte development (Najeba \& Mohamad 2013). Their toxicity impairs the production of estradiol and progesterone. Moreover, trace metals play a role in increasing fertility problems and affect the hypothalamic-pituitary-ovarian axis (Tasneem et al. 2008).

Toxicity by one trace element may cause a deficiency or disturb the bioavailability of another element (Cepeda-Lopez et al. 2011). High tissue copper aggravates obesity and tends to raise tissue sodium levels while lowering tissue potassium levels, subsequently resulting in water retention (Demer- 
dash 2015, Fan et al. 2017). Higher prevalence of Iron (Fe) deficiency has been reported in obese children and females than in males (Ferrari et al. 2011). Hence the objective of the study was to investigate the concentrations of trace metals in blood samples of obese females living around a mining industry and to examine the overall effect on reproductive hormones of obese females.

\section{MATERIALS AND METHODS}

\section{Study Design}

A mixed research approach consisting of a qualitative and quantitative cross-sectional descriptive survey was carried out. For the analysis of blood samples collected, ICP-MS was used to determine the concentrations of trace metals in the blood of the obese individuals used in the study.

\section{Study Setting}

The study was carried out in a mining area situated in Brits/ North West, South Africa [25 $44^{\prime} 46^{\prime}$ S; $28^{\circ} 11^{\prime} 17^{\prime}$ E]. An initial visit to the area showed 82 housing units. It was assumed from the study that each housing unit had either a young female or adult member living in them. According to the report provided by De Ridder \& Coetzee (2015), 70\% of women in South Africa are reported to be obese, hence it is envisaged to have about 57 obese females from the mining area who may qualify to participate in the study. However, a total of 40 obese females (aged 16-45 years) participated in the study.

\section{Sample/Study Population}

Female teenagers ( $\geq 18$ years) and adults aged $18-45$ years with $\mathrm{BMI} \geq 30$ were identified and participated in the study. A written informed consent form was distributed to participants. Due to the sensitivity of the study, the identity of participants was protected. No unique identifier was used and the study was conducted with only willing participants.

Blood samples were collected from each female participant. Blood was drawn by vein puncture by a certified professional from participants under contamination controlled conditions. Blood samples were collected in two $5 \mathrm{~mL} \mathrm{BD}$ Vacutainer sterile glass tubes certified for trace metals analysis and hormonal assay. An amount of 143 USP units of sodium heparin was put in each tube (only for trace metal analysis) as an anticoagulant. Tubes were enclosed with a royal blue coloured Hemogard enclosure then taken to National Institute for Occupational Health (NIOH) accredited lab for trace metal analysis. For hormonal determination, test tubes with a yellow coloured Hemogard closure were used. The samples were then taken to Dr. George Mukhari Academic Hospital National Health Laboratory Services (DGMAH NHLS) for analysis. All blood samples were stored at ambient temperatures until analysed for trace metals and hormonal levels (estradiol and progesterone) within twelve hours

Individuals with $\mathrm{BMI} \geq 30$ but taking mineral supplements and those diagnosed with diabetes were excluded from the study. Females on hormone replacement therapy

Table 1: Characteristics of obese female participants living around a mining area in Brits $(n=40)$.

\begin{tabular}{|ll|}
\hline Variables & Study population \\
\hline Age $($ years $)$ & $67.5 \%$ \\
$18-35$ & $32.5 \%$ \\
$36-45$ & \\
BMI $\left(\mathrm{kg} / \mathrm{m}^{2}\right)$ & $57.5 \%$ \\
$=30$ & $17.5 \%$ \\
$>30<35$ & $25 \%$ \\
$>35$ & \\
Metals $[\mu \mathrm{g} / \mathrm{L} ; \overline{\mathrm{x}} \pm \mathrm{SD}($ Range $)]$ & $12.97 \pm 6.04(6.79-33.99)$ \\
$\mathrm{Mn}$ & $3.70 \pm 4.11(0.41-19.01)$ \\
$\mathrm{Cr}$ & $2.19 \pm 4.43(0.20-18.8)$ \\
$\mathrm{Co}$ & $0.84 \pm 0.41(0.27-2.20)$ \\
As & $0.20 \pm 0.20(0.02-1.10)$ \\
$\mathrm{Cd}$ & $0.67 \pm 0.34(0.50-1.84)$ \\
$\mathrm{Pb}[\mu \mathrm{g} / \mathrm{dL} ; \overline{\mathrm{x}} \pm \mathrm{SD}($ Range $)]$ & \\
$\mathrm{Hormones}$ & \\
Estradiol $[\mathrm{pmol} / \mathrm{L} ; \overline{\mathrm{x}} \pm \mathrm{SD}($ Range $)]$ & $724.95 \pm 2393.24(37-15040.00)$ \\
Progesterone $[\mathrm{nmol} / \mathrm{L} ; \overline{\mathrm{x}} \pm \mathrm{SD}($ Range $)]$ & $6.79 \pm 17.46(0.3-93.50)$ \\
\hline
\end{tabular}


and those using contraceptives were also excluded from the study as this may affect the hormone balance.

\section{RESULTS AND DISCUSSION}

Table 1 shows the results of trace metal analysis and hormonal levels from blood samples collected from obese females living around a mining area in Brits. From the results, the mean concentrations of $\mathrm{Mn}, \mathrm{Cr}, \mathrm{Co}, \mathrm{As}$ and $\mathrm{Pb}$ were higher than the permissible limit for human exposure (WHO 2000). However, the mean concentration of $\mathrm{Cd}$ was lower than the permissible limit.

The mean concentrations of estradiol and progesterone were within the acceptable hormonal range. However, progesterone level was lower than $\leq 15.90 \mathrm{nmol} / \mathrm{L}$ while estradiol was higher than $275 \mathrm{pmol} / \mathrm{L}$ which are levels indicating anovulation levels (Gaskins et al. 2009). A significant and strong positive correlation existed between the blood estradiol levels and progesterone levels $(r=0.88 ; \mathrm{p}<0.01)$, which shows that both hormones influence the increase or decrease of each other. The correlation was also determined among the levels of $\mathrm{Mn}, \mathrm{Cr}, \mathrm{Co}, \mathrm{As}, \mathrm{Pb} \mathrm{Cd}$ and the reproductive hormones (estradiol and progesterone) in the blood of obese females living around a mining area (Table 3 ).

The concentration of $\mathrm{Mn}$ was higher than all the metals with a range of 6.79-33.99 $\mu \mathrm{g} / \mathrm{L}$, a mean of $12.97 \mu \mathrm{g} / \mathrm{L}$ and a standard deviation of 6.04 in obese females. The results also showed that there was a positive correlation between estradiol $(\mathrm{r}=0.08 ; \mathrm{p}>0.05)$ and progesterone $(\mathrm{r}=0.12 ; \mathrm{p}>0.05)$ levels with $\mathrm{Mn}$ concentration. The results showed that an increase in Mn concentrations increases progesterone and estradiol levels. Manganese was also positively correlated with $\mathrm{Co}$ $(\mathrm{r}=0.40 ; \mathrm{p}<0.01)$, where a significant increase in one metal increased the other.

The high levels of Mn recorded in the participants' blood may be due to mining activities since the mine is situated opposite to the informal settlements, industrial activities in the area, vehicular emissions (from the main road next to the informal settlement) and fuel combustion (used for heat in winter and food preparation). The concentration of $\mathrm{Mn}$ in this study is similar to those reported by Fan et al. (2017) with a range 3.21-58.86 $\mu \mathrm{g} / \mathrm{L}$ and mean $10.69 \mu \mathrm{g} / \mathrm{L}$ in obese individuals aged 6-19 years, in the United States, which demonstrated a significant relationship between metallic elements (including blood $\mathrm{Zn}, \mathrm{Cu}, \mathrm{Mn}$, and $\mathrm{Hg}$ ) with obesity, and a positive relationship with BMI, low-density lipoprotein cholesterol (LDL-C), triglyceride, total cholesterol, and homeostatic model assessment of insulin-resistant (HOMA-IR). Their findings showed that the relationship between obesity and metallic elements could be different in obese populations with elevated BMI or changes in other obesity biochemical parameters when compared to populations with lower BMI. The findings of this study also correlate with the findings of Stasys (2007) and Najeba \& Mohamad (2013) which showed that high levels of Mn may affect female health and further impact fertility and fecundity (Gallagher et al. 2010).

The concentration of $\mathrm{Cr}$ ranged between 0.41-19.01 $\mu \mathrm{g} / \mathrm{L}$, a mean of $3.70 \mu \mathrm{g} / \mathrm{L}$ and a standard deviation of 4.11 in obese females. The results showed that there was a weak and negative correlation between $\mathrm{Cr}$ concentration with es-

Table 2: WHO standards/ permissible limits for human exposure to trace metals ( $\mu \mathrm{g} / \mathrm{L})$.

\begin{tabular}{|lllllll|}
\hline Trace Metals & $\mathrm{Mn}$ & $\mathrm{Cr}$ & $\mathrm{Co}$ & $\mathrm{As}$ & $\mathrm{Cd}$ & $* \mathrm{~Pb}$ \\
\hline Levels & 12.60 & 0.23 & 0.30 & 1.00 & 1.12 & 0.08 \\
\hline
\end{tabular}

$*(\mu \mathrm{g} / \mathrm{dL})$

Table 3: Correlations between trace metals and reproductive hormones in the blood of obese females living around a mining area in Brits $(\mathrm{n}=40)$.

\begin{tabular}{|lllllllll|}
\hline Variables & $\mathrm{Mn}$ & $\mathrm{Cr}$ & $\mathrm{Co}$ & $\mathrm{As}$ & $\mathrm{Pb}$ & $\mathrm{Cd}$ & Estradiol & Progesterone \\
\hline $\mathrm{Mn}$ & 1 & 0.143 & $0.404^{* *}$ & 0.088 & 0.027 & 0.007 & 0.078 \\
$\mathrm{Cr}$ & 0.143 & 1 & -0.074 & 0.053 & 0.032 & $0.332^{*}$ & -0.138 \\
$\mathrm{Co}$ & $0.404^{* *}$ & -0.074 & 1 & -0.053 & 0.187 & -0.156 & 0.043 & -0.152 \\
$\mathrm{As}$ & 0.088 & 0.053 & -0.053 & 1 & -0.069 & 0.128 & -0.045 & -0.012 \\
$\mathrm{~Pb}$ & 0.027 & 0.032 & 0.187 & -0.069 & 1 & 0.178 & -0.114 & -0.038 \\
$\mathrm{Cd}$ & 0.007 & $0.332^{*}$ & -0.156 & 0.128 & 0.178 & 1 & -0.054 \\
Estradiol & 0.078 & -0.138 & 0.043 & -0.045 & -0.114 & -0.054 & 1 & 0.014 \\
Progesterone & 0.122 & -0.152 & -0.012 & -0.064 & -0.038 & 0.014 & $0.878^{* *}$ & 1 \\
\hline
\end{tabular}

$*(\mathrm{p}<0.05), * *(\mathrm{p}<0.01)$ 
tradiol $(\mathrm{r}=-0.14 ; \mathrm{p}>0.05)$ and progesterone $(\mathrm{r}=-0.15 ; \mathrm{p}>0.05)$ levels. This means that higher $\mathrm{Cr}$ concentrations above the permissible limit lower the progesterone and estradiol levels (Table 3). The high levels of $\mathrm{Cr}$ in the blood of participants may be as a result of emissions from a chromium mine next to the informal settlement and several industries such granite cutting and tire manufacturing industries located within a 3 $\mathrm{km}$ radius from the informal settlement. Other sources of $\mathrm{Cr}$ may be due to the combustion of fossil fuels and cigarette smoking. Since the participants were not active smokers, the high levels of $\mathrm{Cr}$ in their blood may be as a result of smoke emission from the mine next to the residential area as well as the result of passive smoking as reported by Paakko et al. (1989) and Bernhard et al. (2015). Their findings show that concentrations of about $4.3 \mathrm{mg} / \mathrm{kg}$ (dry weight) are found in smokers compared to $1.3 \mathrm{mg} / \mathrm{kg}$ in non-smokers, increasing with age and smoking time.

According to Martin \& Griswold (2009) and Tangahu et al. (2011), chromium is known as a carcinogen, which causes skin cancer, lung cancer and inflammation of the blood vesicles. High levels of Cr reported in a study by Ajayi et al. (2012), showed Cr levels of $45.16 \pm 1.16 \mu \mathrm{g} / \mathrm{dL}$ may disturb the production of reproductive hormones and interfere with normal oocyte development. Furthermore, it has been reported to cause spontaneous abortions and result in low birth weight (Bonde et al. 1992, Hjollund et al. 1995, Hertz-Picciotto 2000, Ajayi et al. 2012). Since decreasing progesterone levels were reported with high concentrations of $\mathrm{Cr}$, we can deduce that our findings agree with those found in the literature (Hertz-Picciotto 2000, Ajayi et al. 2012), that spontaneous abortion can occur as a result of high $\mathrm{Cr}$ concentrations and low progesterone levels in the blood.

Cobalt concentrations in the blood of obese females ranged between $0.20-18.84 \mu \mathrm{g} / \mathrm{L}$, with a mean of $2.19 \mu \mathrm{g} / \mathrm{L}$ and a standard deviation of $4.43 \mu \mathrm{g} / \mathrm{L}$. The results showed that there was no correlation between Co concentrations with estradiol $(r=0.04 ; p>0.05)$ and progesterone $(r=-0.01$; $\mathrm{p}>0.05$ ) levels (Table 3 ). The results of this study show that high Co concentrations do not affect the levels of both hormones (estradiol and progesterone). However, in another study carried out by Philippe (1975), Co radiation at high doses has been shown to elicit pro-found decrements in reproductive ability in animal species. The study further shows that single doses of $>100 \mathrm{rad}$ of Co radiation cause decreased fertility in exposed female mice. Their findings further show that continuous exposure of female mice to an average daily dose 8-16 rad/day causes a decreased number of offspring per litter and decreased reproductive performance, with $100 \%$ sterility occurring at 32 weeks of exposure at $8 \mathrm{rad} /$ day. Pedigo \& Vernon (1993), reported that cobalt dichloride
(400 ppm in drinking water for 10 weeks) increases pre-implantation losses of pregnant female rats.

Sources of high levels of Co recoded from the participants may be as a result of the consumption of alcoholic beverages (beer) which participants were observed to highly indulge in. Other problems associated with high Co apart from the mining activities is the consumption of large quantities of alcoholic beverages (beer) which may contain foam stabilizers such as cobalt sulphate $\left(\mathrm{CoSO}_{4}\right)$ or cobalt chloride $\left(\mathrm{CoCl}_{2}\right)$. Reports show that individuals who consume a lot of beer with $\mathrm{CoSO}_{4}$ have suffered from cardiomyopathy which is the weakening of the heart (Alexander 1972, Bonenfant et al. 1969, Morin \& Daniel, 1967). Alcohol and heart conditions may have fatal consequences on obese individuals, especially when coupled with trace metal exposure from different sources of pollutants. Other sources contributing to high Co levels in the blood of participants include occupational exposure (cobalt-containing alloys and salts) and environmental contamination due to industrial activities in Brits. Cobalt has also been reported to be carcinogenic in humans. Exposure to Co may initiate an inflammatory process that infiltrates the T- lymphocytes (immune-mediated cells) and increase the body's hypersensitivity response. There are no studies on the reproductive or developmental effects of Co exposure in humans, to the best of our knowledge, however, studies have reported on stunted growth and decreased survival of newborn puppies [Agency for Toxic Substances and Disease Registry (ATSDR) 1992, California Environmental protection Agency (CalEPA) 1997)].

The mean concentration of As in the blood of obese female participants were below the permissible limit of 1.00 $\mu \mathrm{g} / \mathrm{L}$. The mean concentration was $0.84 \pm 0.41 \mu \mathrm{g} / \mathrm{L}$ with a range of $0.27-2.20 \mu \mathrm{g} / \mathrm{L}$ (Table 1). However, $29.3 \%$ of the participants recorded, had As value higher than $1.00 \mu \mathrm{g} / \mathrm{L}$. The results from Table 3 shows that there was a weak negative correlation between As and hormonal levels progesterone ( $\mathrm{r}=$ $-0.06 ; \mathrm{p}>0.05$ ) but there was no correlation with estradiol ( $r=$ $-0.04 ; p>0.05$ ). This shows that as the concentrations of As increases, there was a decrease in the levels of progesterone but no effect on estradiol levels.

Arsenic is carcinogenic, it causes cancer in soft organs, skin, lungs, liver and bladder (Martin \& Griswold 2009, Tangahu et al. 2011). Sources of As in the environment include mining or industrial activates as well as lifestyle activities such as cigarettes smoking. Literature shows that no similar studies have been done on the effects of As on obese females and reproductive hormones. However, a study by Akram et al. (2010), examined the adverse effects of As exposure on uterine function and structure of female rats. The study findings show that there was a dose-dependent decrease observed in 
mean uterine diameter, epithelial height, the thickness of the endometrium, myometrium, and in plasma levels of estradiol, progesterone, FSH and LH in all the treatment groups compared to control at 100 and $200 \mathrm{ppm}$ of sodium arsenite in drinking water. The study concluded that arsenic is a major threat to female reproductive health, acting as a reproductive toxicant and as an endocrine disruptor. The study further showed that As restricted the function and structure of the uterus, by altering the gonadotropins and steroid levels, not only at high dose concentration but also at low (50 ppm) levels, when the rats become mature.

The concentration of $\mathrm{Pb}$ was also higher than the permissible limit of $0.08 \mu \mathrm{g} / \mathrm{dL}$ value with a mean of $0.67 \pm$ $0.34 \mu \mathrm{g} / \mathrm{dL}$ and range of $0.50-1.86 \mu \mathrm{g} / \mathrm{dL}$. A weak negative correlation existed between $\mathrm{Pb}$ concentration and levels of estradiol $(\mathrm{r}=-0.11 ; \mathrm{P}>0.05)$ however no correlation was established between $\mathrm{Pb}$ concentration and progesterone $(\mathrm{r}=$ -0.04; $\mathrm{p}>0.05$ ) levels. Therefore, higher levels of $\mathrm{Pb}$ above the permissible limit indicated a decrease in estradiol levels, while there was no effect on progesterone levels. Sources of $\mathrm{Pb}$ may be as a result of mining, paint, vehicular emissions and industrial activities.

When compared to the study by Ajayi et al. (2012), the mean concentration of lead was higher with a mean of 85.96 $\pm 1.09 \mu \mathrm{g} / \mathrm{dL}$. However, their results showed that elevated serum levels of $\mathrm{Pb}$ may contribute to spontaneous abortion by lowering the progesterone levels. High levels of $\mathrm{Pb}$ have also been recorded in studies by Sekhar et al. (2009) and Patrick (2006), where it was reported that once $\mathrm{Pb}$ has been absorbed in the blood, it can decrease the number of red blood cells and lead to anaemia. According to Najeba \& Mohamad (2013), $\mathrm{Pb}$ has also been detected in human follicular fluid (liquid composed primarily of hormones) which interferes with reproduction. In expectant females, prolonged exposure to high levels of $\mathrm{Pb}$ may lead to spontaneous abortions, premature delivery and low birth weights (UK Teratology Information Services 2010). This condition also has a direct effect of female fecundity especially when obesity is also a factor.

The lowest value of all the metals was recorded for $\mathrm{Cd}$ in the blood of obese female participants. Cd levels were below the permissible limit with a mean value of $0.20 \pm 0.20 \mu \mathrm{g} / \mathrm{L}$ and a range of $0.02-1.10 \mu \mathrm{g} / \mathrm{L}$. There was no correlation between $\mathrm{Cd}$ and progesterone ( $\mathrm{r}=0.01)$ levels but a negative and weak correlation between $\mathrm{Cd}$ and estradiol $(\mathrm{r}=-0.05)$ levels was established. Correlations showed that as the concentrations of $\mathrm{Cd}$ increases, the level of progesterone were not affected, however, there was a decrease in the levels of estradiol.

Detected Cd levels in the blood of participants maybe as a result of household items such as detergent, paint, vehicular emissions and mining activities near the residential area. In a study by Ajayi et al. (2012), the mean concentration of lead was higher than the permissible limit set by WHO (2000), with a mean of $45.8 \pm 0.77 \mu \mathrm{g} / \mathrm{L}$. Their findings showed that high serum levels of $\mathrm{Cd}$ may contribute to spontaneous abortion due to its effect on progesterone levels.

However, even though lower levels have been recorded for As and Cd (Table 2), close monitoring is required as these metals may bioaccumulate and affect human health. The results show that there was a positive correlation between $\mathrm{Mn}$ levels and Co levels in the blood $(\mathrm{r}=0.40 ; \mathrm{p}<0.01)$. Blood $\mathrm{Cr}$ levels also showed a positive correlation with blood Cd levels $(r=0.33 ; p<0.05)$. This observation showed that an increase in one metal had an impact on the increase of another metal.

Generally, from the results, obese participants with progesterone levels of $<0.3 \mathrm{nmol} / \mathrm{L}$ recorded high concentrations of $\mathrm{Cr}$, $\mathrm{Co}$ and $\mathrm{Pb}$. Moreover, an obese female participant with a high level of estradiol (3462 pmol/L) also had the highest Mn $(33.99 \mu \mathrm{g} / \mathrm{L})$ concentration in the blood. Several studies have suggested a link between trace metal exposure and hormonal variations (Gallagher et al. 2010, Pollack et al. 2011).

Furthermore, females with variations in reproductive hormone levels are considered at risk for cardiovascular diseases (Rossouw et al. 2002) breast cancer and ovarian cancer (Brinton et al. 1988). This study agrees with the findings of Aksel et al. (1976) and Lutoslawska et al. (2006) which showed that hormonal alterations may increase anovulation, with effects on fertility. Especially if these alterations are as a result of high levels of trace metals found in the blood. According to Tasneem et al. (2008), the prevalence of infertility in industrialized countries has increased from $8 \%$ to $15 \%$ over the past 2 decades. Ultimately these toxic metals may result in complications including fertility, fecundity and nulliparity (Najeba \& Mohamad 2013). The association between metal toxicity and hormonal variations in obese females could have dire consequences for female reproductive health, which may lead to infertility.

\section{CONCLUSION}

The study showed that exposure to trace metals as pollutants may have an impact on the general and reproductive health of obese females living around mining activities. From the results, it can be concluded that mining activity may pose a high potential risk to these obese females' general health as well. However, the participants' exposure to trace metals found in the blood from the mining area may be as a result of multi pathways. The findings of this study cannot be generalizable due to the limitation of a small sample size. Furthermore, mechanisms on the impact of trace metals on reproductive 
health are yet to be understood. More detailed and in-depth mechanisms on trace metals and reproductive health relationship are necessary for the future to examine whether adverse health outcomes occur, and provide decision-making support for pollution control in this metal-polluted area accordingly. Further research is underway with regards to understanding mechanisms on trace metals reproductive health of obese females exposed to mining activities.

\section{ACKNOWLEDGEMENTS}

The authors wish to acknowledge the Department of Biology, Sefako Makgatho Health Sciences University and Research Development Grant (RDG) for the financial support to carry out this research.

\section{REFERENCES}

Ajayi, O.O., Charles-Davies, M.A. and Arinola O.G. 2012. Progesterone, selected heavy metals and micronutrients in pregnant Nigerian women with a history of recurrent spontaneous abortion. African Health Sciences, 12(2): 153-159.

Alexander, C.S. 1972. Cobalt-beer cardiomyopathy: A clinical and pathologic study of twenty-eight cases. The American Journal of Medicine, 53(4): 395-417.

Albering, H.J., van Leusen, S.M., Moonen, E.J.C., Hoogewerff, J.A. and Kleinjans, J.C.S. 1999. Human health risk assessment: A case study involving heavy metal soil contamination after the flooding of the river Meuse during the winter of 1993-1994. Environmental Health Perspective, 107: 37-43.

Akram, Z., Jalali, S. and Shami S.A. 2010. Adverse effects of arsenic exposure on uterine function and structure in female rat. Experimental Toxicology Pathology, 62: 451- 459.

Aksel S., Wiebe, R.H., Tyson, J.E. and Jones, G.S. 1976. Hormonal findings associated with a luteal cycle. Obstetrics and Gynecology, 48: 598-602.

[ATSDR] Agency for Toxic Substances and Disease Registry. 1992. Impact of lead contaminated soil on public health. Atlanta: U.S. Department of Health and Human Services.

Baastrup, R., Sørensen M, Balstrøm, T., Frederiksen, K. and Larsen, C.L. 2008. Arsenic in drinking-water and risk for cancer in Denmark. Environmental Health Perspective, 116(231).

Bernhard, D., Rossmann, A. and Wick, G. 2015. Metals in cigarette smoke. IUBMB Life, 57(12): 805-809.

Błażewicz, A., Klatka, M., Astel, A., Partyka, M. and Kocjan R. 2013. Differences in trace metal concentrations ( $\mathrm{Co}, \mathrm{Cu}, \mathrm{Fe}, \mathrm{Mn}, \mathrm{Zn}, \mathrm{Cd}$ and $\mathrm{Ni}$ ) in whole blood, plasma, and urine of obese and nonobese children. Biological Trace Elements Research, 55(2): 190-200.

Bloom, M.S., Louis, G.M., Sundaram, R., Kostyniak, P.J. and Jain, J. 2011. Associations between blood metals and fecundity among women residing in New York State. Reproductive Toxicology, 31(2): 158-63.

Bonde, J.P.E., Olsen, J.H. and Hansen, K.S. 1992. Adverse pregnancy outcome and childhood malignancy with reference to paternal welding exposure. Scandinavian Journal of Work and Environmental Health, 18: $169-177$.

Bonenfant, J.L., Auger, C., Miller, G., Chenard, J. and Roy, P.E. 1969. Quebec beer-drinkers' myocarditis: Pathological aspects. Annals of the New York Academy of Science, 156 (1): 577-582.

Brinton, L.A., Schairer, C., Hoover, R.N.F. and Fraumeni, J.F. 1988. Menstrual factors and risk of breast cancer. Cancer Investigation, 6: 245-254.

Choe, S.Y.K., So-Jung, K., Hae-Gyoung, L., Ji, C., Younghee, L. and Hun, K.Y. 2003. Evaluation of estrogenicity of major heavy metals.
The Science of the Total Environment, 15(21): 312 10.1016/S0048 9697(03)00190-6.

CDC, Third National Report on Human Exposure to Environmental Chemicals. 2005. http://www.jhsph.edu/research/centers-and-institutes/ center-for-excellence-in-environmental-health-tracking/Third_Report. pdf.

Chang, S.H., Cheng, B.H., Lee, S.L., Chuang, H.Y., Yang, C.Y. and Sung, F.C. 2006. Low blood lead concentration in association with infertility in women. Environmental Research, 101 (3): 380-386.

Cepeda-Lopez, A.C., Osendarp, S.J., Melse-Boonstra, A., Aeberli, I., Gonzalez-Salazar, F., Feskens, E., Villalpando, S. and Zimmermann, M.B. 2011. Sharply higher rates of iron deficiency in obese Mexican women and children are predicted by obesity-related inflammation rather than by differences in dietary iron intake. American Journal of Clinical Nutrition, 93: 975-983.

CalEPA/ DTSC. 1997. Selecting Inorganic Constituents as Chemicals of Potential Concern at Risk Assessment at Hazardous Waste Facilities. Final Policy. Human and Ecological Risk Division, DTSC.

Demerdash, H.M. 2015. Obesity and trace elements. Obesity Research Open Journal, 2(3): 98-100.

Denier, X. and Hill, E.M.2009. Estrogenic activity of cadmium, copper and zinc in the yeast estrogen screen. Toxicology in vitro, 23: 569-573.

De Ridder, J.H. and Coetzee, D. 2013. Childhood obesity in South Africa: Are we sitting on a time bomb? Global Journal of Health and Physical Education Pedagogy, 2: 239-249.

Flora, S.J.S., Mittal, M. and Mehta, A. 2008. Heavy metal induced oxidative stress \& its possible reversal by chelation therapy. Indian Journal of Medical Research, 128: 501- 523.

Feldman, A., Aigner, E., Weghuber, D, and Paulmichl, K. 2015. The Potential role of iron and copper in pediatric obesity and nonalcoholic fatty liver disease. Biomedical Research International Article. https:// doi.org/10.1155/2015/287401.

Fan, Y., Zhang, C. and Bu, J. 2017. Relationship between selected serum metallic elements and obesity in children and adolescent in the U.S. Nutrients, 9(2): 104.

Ferrari, P., Kulkarni, H., Dheda, S., Betti, S., Harrison, C., Timothy, G., Pierre, S.t. and Olynyk, J.K. 2011. Serum iron markers are inadequate for guiding iron repletion in chronic kidney disease. Clinical Journal of American Society of Nephrology, 6: 77-83.

Georgescu, B., Georgescu, Cărăban, S., Bouaru, A. and Paşcalău, S. 2011. Heavy Metals acting as endocrine disrupters. Animal Science and Biotechnologies, 44(2): 89.

Guével, R., Petit, F.G., Le Goff, P., Métivier, R., Valotaire, Y. and Pakdel, F. 2000. Inhibition of rainbow trout (Oncorhynchus mykiss) estrogen receptor activity by cadmium. Biology Reproduction, 63: 259-266.

Gallagher, C.M., Moonga, B.S. and Kovach, J.S. 2010. Cadmium, follicle-stimulating hormone, and effects on bone in women age 42-60 years, NHANES III. Environmental Research, 110(1): 105-11.

Guo, Z., Guo, H. and Xia, Y. 2011. Effects on endocrine system of female rats exposed to chronic arsenic. Journal of Hygine Research, 40(2): 178-179.

Gaskins, A.J., Mumford, S.L., Zhang, C., Wactawski-Wende, J., Hovey, K.M., Whitcomb, B.W., Howards, P.P., Perkins, N.J., Yeung, E. and Schisterman, E.F. 2009. BioCycle Study Group. Effect of daily fiber intake on reproductive function: the BioCycle Study. American Journal of Clinical Nutrition, 90: 1061-1069.

Hjollund, N., Bonde, J.S. and Hansen, K. 1995. Male-mediated risk of spontaneous abortion with reference to stainless steel welding. Scandinavian Journal of Work, Environment \& Health, 21(10): 5271/sjweh. 37.

Hertz-Picciotto, I. 2000. The evidence that lead increases the risk for spontaneous abortion. American Journal of Industrial Medicine, 38: 300-309.

Hough, R.L., Breward, N., Young, S.D., Crout, N.M.J. and Tye, A.M. 2004. Assessing potential risk of heavy metal exposure from consumption of home-produced vegetables by urban populations. Environmental Health Perspective, 112(215). 
Jarup, L. 2003. Hazards of heavy metal contamination. British Medical Bulletin, 68: 167-182.

Koz, B., Cevik, U. and Akbulut, S. 2012. Heavy metal analysis around Murgul (Artvin) copper mining area of Turkey using moss and soil. Ecological Indicators, 20: 17-23

Krieg, E.F. 2007. The relationships between blood lead levels and serum follicle stimulating hormone and luteinizing hormone in the Third National Health and Nutrition Examination Survey. Environmental Research, 104(3): 374-82.

Lambert, M., Leven, B.A. and Green, R.M. 2000. New methods of cleaning up heavy metal in soils and water. Environmental Science and Technology Briefs for Citizens; Manhattan, KS: Kansas State University.

Langley, S.A. 2014. Nutrition Screening Form for Female Infertility Patients. Canadian Journal of Dietetic Practice and Research, 75(4): 195-201.

Lion, G.N. and Olowoyo, J.O. 2012. Population health risk due to dietary intake of toxic heavy metals from Spinacia oleracea harvested from soils collected in and around Tshwane, South Africa. South African Journal of Botany, 88: 178-182.

Lutoslawska, G., Niedbalska, M., Skierska, E., Keska, A., Szpocinska-Byszewska, E. and Zolnowska, M. 2006. Plasma proinsulin, $\mathrm{C}$-peptide and sex hormone concentrations in regularly menstruating premenopausal females with ovulatory and anovulatory menstrual cycles. Journal of Sports Medical and Physical Fitness, 46: 138-142.

MacIntosh, D.L., Kabiru, C., Scanlon, K.A. and Ryan, P.B. 2000. Longitudinal investigation of exposure to arsenic, cadmium, chromium and lead via beverage consumption. Journal of Exposure Analysis and Environmental Epidemiology, 10(2): 196-205.

Mari, M, Nadal, M., Schuhmacher, M. and Domingo, J.L. 2009. Exposure to heavy metals and PCDD/Fs by the population living in the vicinity of a hazardous waste landfill in Catalonia, Spain: Health risk assessment. Environment International, 35: 1034-1039.

Man, Y.B., Sun, X.L., Zhao, Y.G., Lopez, B.N. and Chung, S.S. 2010. Health risk assessment of abandoned agricultural soils based on heavy metal contents in Hong Kong, the world's most populated city. Environment International, 36: 570-576.

Monisha, J., Tenzin, T., Naresh, A., Blessy,B.M. and Krishnamurthy N.B. 2014. Toxicity, mechanism and health effects of some heavy metals. Interdisciplinary Toxicology, 7(2): 60-72.

Mendola, P., Messer, L.C. and Rappazzo, K. 2008. Science linking environmental contaminant exposures with fertility and reproductive health impacts in the adult female. Fertility Sterility., 89(2): 81-94

Martin, S. and Griswold, W. 2009. Human health effects of heavy metals. Environmental Science and Technology Briefs from Citizens, 15: 1-6.

Morais, S., Costa, F.G. and Pereira, M.L. 2012. Heavy metals and human health. In: Oosthuizen, J. (eds). Environmental Health-emerging Issues and Practice. 227-246.

Morin, Y. and Daniel, P. 1967. Quebec beer-drinkers' cardiomyopathy: Etiological considerations. Canadian Medical Association Journal, 97: 926-928.

Nagata, C., Nagao, Y., Shibuya, C., Kashiki, Y. and Shimizu, H. 2005. Urinary cadmium and serum levels of estrogens and androgens in postmenopausal Japanese women. Cancer Epidemiology Biomarkers and Prevention, 14(3): 705-708.

Najeba, S. and Mohamad J. 2013. Heavy metals in blood and urine impact on the woman fertility. Chemistry and Materials Research, 3(3): 2224-3224

Olowoyo, J.O, Odiwe, A.L., Mkolo, N.M. and Macheka, L. 2013. Investigating the concentration of different elements in soil and plant composition from mining area. Polish Journal of Environmental Studies, 22: $1135-1141$
Olowoyo, J.O. and Lion, G.N. 2016. Urban farming as a possible source of trace metals in human diets. South African Journal of Science, 112(1/2): 2014 - 0444, 6.

Paakko, P., Kokkonen, P., Anttila, S. and Kalliomaki PL. 1989. Metals in cigarette smoke. Environmental Research, 49: 197-207.

Paksy, K., Gáti, I., Náray, M. and Rajczy, K. 2001. Lead accumulation in human ovarian follicular fluid, and in vitro effect of lead on progesterone production by cultured human ovarian granulosa cells. Journal of Toxicology and Environmental Health, Part A, 62(5): 359-366.

Patrick, L. 2006. Lead toxicity, part II: The role of free radical damage and the use of antioxidants in the pathology and treatment of lead toxicity. Alternative Medical Review, 11: 114-126.

Pedigo, N.G. and Vernon, M.W. 1993. Embryonic losses after 10-week administration of cobalt to male mice. Reproductive Toxicology, 7: 111-116.

Philippe, J.V. 1975. Fertility and irradiation: A preconceptional investigation in teratology. American Journal of Obstetrics and Gynecology, 123(7): 714-718.61.

Pollack, A.Z., Schisterman, E.F. and Goldman, L.R. 2011. Cadmium, lead, and mercury in relation to reproductive hormones and anovulation in premenopausal women. Environmental Health Perspective, 119(8): $1156-1161$.

Rossouw, J.E., Anderson, G.L., Prentice, R.L., Lacroix, A.Z., Kooperberg, C. and Stefanick, M.L. 2002. Risks and benefits of estrogen plus progestin in healthy postmenopausal women: principal results from the Women's Health Initiative randomized controlled trial. Journal of American Medical Association, 288: 321-333.

Saleh, I., Coskun, S., Mashhour, A., Shinwari, N., El-Doush, I. and Billedo, G. 2008. Exposure to heavy metals (lead, cadmium and mercury) and its effect on the outcome of in-vitro fertilization treatment. International Journal of Hygiene and Environmental Health, 211(5-6): 560-579.

Sekhar, K.C. 2009. Environmental risk assessment studies of heavy metal. contamination in the industrial area of Kattedan, India- a case study. UK Human and Ecological Risk Assessment: An International Journal, 12(2): 37-41 408-422.

Sengupta, P., Banerjee, R., Nath, S., Das, S. and Banerjee, S. 2015. Metals and female reproductive toxicity. Human Exposure Toxicology, 34(7): 679-97.

South African Medical Research Council (SAMRC). 2015. Statistics South Africa and the Department of Health. Annual Report.

Stasys, T. 2007. Investigation of distribution of heavy metals between blood plasma and blood cell Annali di Chimica. Società Chimica Italiana, 97: 1139 .

Stoica, A. 2000. Activation of estrogen receptor- by the heavy metal cadmium. Molecular Endocrinology, 14: 10.1210/me.14.4.545.

Tasneem, G.K. 2008. Copper, chromium, manganese, iron, nickel, and zinc levels in biological samples of diabetes mellitus patients. Biological Trace Elements Research, 122: 1-18

Tangahu, B.V., Abdullah, S.R.S., Basri, H., Idris, M., Anuar, N. and Mukhlisin, M. 2011. A review on heavy metals ( $\mathrm{As}, \mathrm{Pb}$, and $\mathrm{Hg}$ ) uptake by plants through phytoremediation. International Journal of Chemistry and Engineering, 2011.

Tokar, E.J., Benbrahim-Tallaa, L. and Waalkes, M.P. 2011. Metal ions in human cancer development. Metal Ions in Life Science, 8: 375-401.

UK, Teratology Information Service Beta-adrenoceptor blocking drugs in pregnancy monograph. 2010. Retrieved from http://www.toxbase.org.

Wang, X., Sato, T., Xing, B. and Tao, S. 2005. Health risks of heavy metals to the general public in Tianjin, China via consumption of vegetables and fish. Science of the Total Environment, 350: 28-37. 
Wang, X.Q., He, M.C., Xie, J., Xi, J.H. and Lu, X.F. 2010. Heavy metal pollution of the world largest antimony mine-affected agricultural soils in Hunan province (China). Journal of Soils Sediments, 10: 827-837.

World Health Organization 2015. Sexual and reproductive health: Infertility is a global public health issue.
WHO 2000. Air Quality Guidelines for Europe (2nd Edn.), World Health Organization Regional Publications European Series No.91.

Zhang, J.M., Konkle, A.T., Zup, S.L. and McCarthy, M.M. 2008. Impact of sex and hormones on new cells in the developing rat hippocampus: A novel source of sex dimorphism? Europian Journal of Neuroscience, 27(4): 791-800. 